\title{
INCUMBENCY AdVANTAGE AND TENURE LENGTH IN the Chilean Chamber of Deputies, 1989-2009*
}

\author{
Ventaja de los legisladores titulares y duración de las carreras \\ en la Cámara de Diputados de Chile, 1989-2009
}

\section{KENNETH BUNKER}

The London School of Economics and Political Science

\section{PATRICIO NAVIA}

Universidad Diego Portales

\begin{abstract}
This article explores incumbency advantage and tenure length in the Chilean Chamber of Deputies between 1989 and 2009. After describing how the electoral system frames electoral competition, we present descriptive data of incumbency advantage and tenure length. There is remarkable stability in both indicators. Three out of four incumbents seek re-election, $82.3 \%$ get re-elected. Still, every four years, first-termers comprise $38.5 \%$ of the 120 -member Chamber. The average tenure length is 2.4 terms. We find a neutral effect of past electoral performance and number of terms in office on the decision to seek re-election and be reelected. However, the results become significant when we control for the incumbent legislators coalition.
\end{abstract}

Key words: Incumbency advantage, tenure length, legislative elections, chilean Congress.

\section{RESUMEN}

Este artículo explora la ventaja de los legisladores titulares y la duración de las carreras en la Cámara de Diputados en Chile entre 1989 y 2009. Después de explicar cómo el sistema electoral afecta la competencia, presentamos evidencia descriptiva de la ventaja de los titulares y la duración de las carreras. Hay alta estabilidad en ambos indicadores. Tres de cada cuatro titulares buscan la reelección, el 82,3\% lo logra. Aun así, cada cuatro años 38,5\% de los 120 miembros son debutantes. La duración promedio es 2,4 periodos. Encontramos un efecto neutro del margen de victoria en la elección previa y el número de periodos en el poder sobre la decisión de buscar la reelección y ser reelegido. Sin embargo, los resultados se vuelven significativos cuando controlamos por la coalición del titular que busca la reelección.

Palabras clave: Ventaja de titulares, carreras legislativas, elecciones legislativas, Congreso chileno. 


\section{INCUMBENCY ADVANTAGE IN THE CHILEAN CHAMBER OF DEPUTIES (1989-2009)}

Twenty-four years after the restoration of democracy in 1990, there is remarkable stability in incumbency advantage in the Chilean Congress. After some attention was paid to legislative incumbency advantage and tenure length in the 1990s, a longer time span allows us to complement those early findings. Although Chile has a different electoral system than the U.S., the binominal system in place in Chile produces a structure of competition that can be compared to the uninominal system in the U.S. The competition in Chile is mostly within lists, not between lists, as the two seats in every district are normally equally divided among the two coalitions, the Concertación and Alianza. Elections in the Chamber of Deputies can be treated as two concurrent races, one in the Concertación and one in the Alianza. In most cases, the winner of each race gets a seat in the Chamber.

We draw on existing theories of incumbency developed using the American case to explore the state of incumbency advantage in the Chilean Chamber of Deputies between 1989 and 2014. Three out of four incumbents seek re-election, $82.3 \%$ get re-elected. Still, every four years $38.5 \%$ of the 120 -member Chamber is comprised by first termers. The average tenure length is 2.4 terms. We assess the effect of the margin of victory in the previous election and the number of terms in office over the decision to seek re-election and the probability of winning a seat. Using district-level data, and contrary to the expectations, we report that a better electoral performance in the previous election and having served more terms in power does not increase the likelihood to seek re-election or increase the probability of being reelected.

The first section discusses the theory. The second section outlines the hypotheses. The third section describes incumbency advantage and tenure length in Chile. We describe how electoral rules influence the party system and frame electoral competition. We present reelection rates and seniority levels from 1989 to 2009. The fourth section presents the breakdown of the district-level data for all 60 congressional districts held in 6 Chamber of Deputies elections between 1989 and 2009. We test four hypotheses. First, that a larger margin of victory in the previous election makes it more likely for an incumbent to seek re-election. Second, that as the number of terms an incumbent serves in office increases, the likelihood he will seek reelection increases. Third, that a larger margin of victory in the previous election makes it more likely for an incumbent to win a seat. Fourth, that as the number of terms an incumbent serves in office increases, the likelihood he will win a seat increases.

\section{THEORIES OF INCUMBENCY AND TENURE}

Democracy is based on a premise of competition, alternation, transparency and representation. These criteria ensure uncertainty in elections (Dahl, 1971). Candidates participate because they believe they have a chance of winning (Przeworski, 1991). 
Electoral competition must be framed under the logic of ambition. The theory of legislative behavior (the theory of ambition) suggests two approaches to understand why legislators are re-elected and endure in power. One approach argues that Congress acts as a springboard for politicians that intend to reach more important positions. In Brazil, for example, Samuels explains that being elected a deputy is commonly regarded as the first step of a political career (2002). Something similar happens in Argentina, where only about $20 \%$ of deputies are re-elected. According to Mustapic, the Argentinean Congress is a place of passage for politicians who aspire to advance to executive positions in their provinces (2006).

A second approach argues that Congress is the final destination of politicians. This generally occurs in countries that are not federally decentralized. Powerful politicians generally choose nationally visible positions, where they can influence national policy, rather than in local elections, where policy leverage is lower. Less powerful politicians generally climb up the ranks, starting as local leaders, before they reach national attention.

Significant attention has been paid to the characteristics of the competition between incumbents and challengers (Erikson, 1971; Fenno, 1978; Ferejohn, 1977; Mayhew, 1974b; Parker, 1980; Tufte, 1973). Incumbents have a natural advantage (Fiorina, 1989). Ferejohn (1995) argues that incumbency advantage occurs because elections orbit around incumbents, rather than challengers. Thus, voters punish or reward incumbents for their past achievements.

Incumbency advantage is the difference between the vote share a candidate receives when competing as the incumbent, and the vote share the same candidate in the same election receives when competing as the challenger. Holding all variables constant, including the underlying quality and talent of the candidate, how much better will he perform as an incumbent compared to the counterfactual scenario where he is a challenger? Incumbency advantage is understood as the set of reasons a candidate may benefit from his incumbency status. This may be because of increased name recognition and media exposure, previous constituency service, experience from having held office, franking privileges or improved ability to fend off high-quality challengers (Fowler and Hall, 2012).

Three sets of theories are commonly used to explain incumbency advantage. The first set argues that voters feel closer to incumbents than to challengers. When "new voters" are redistricted in the U.S. into an incumbent's district, they are less likely to support the incumbent compared to the district's "old voters", suggesting that incumbents benefit from a "personal vote" (Ansolabehere, Snyder Jr, and Stewart III, 2000; Desposato and Petrocik, 2003). Since voters usually operate with information shortcuts, which naturally benefit the better-known candidate (Popkin, 1995), as long as the incumbent performs reasonably well, voters tend to vote for him over the presumably less-known challenger. Also, models that assume stable voter preferences (Angus et al., 1960; Lazarsfeld, Berelson, and, Gaudet, 1944) predict that incumbents will be re-elected because they belong to the dominant party. In this line, explanations for partisan incumbency advantage have also been advanced (see Fowler and Hall, 2012). 
The second set of theories focuses on the behavior of incumbents. Incumbents use their privileged access to information to conduct a more efficient campaign (Alesina and Rosenthal, 1995). Because they know more about the preferences of their constituencies, incumbents gain a head start (Fiorina, 1989). This has induced a built-in institutional advantage that encourages legislators to seek re-election simply because they have a higher chance of winning (Ansolabehere and Snyder, 2002; Cox and Katz, 1996; Gaines, 1998; Jacobson, 1981). As Gordon and Landa (2009) argue, sources of electoral advantage are available to incumbents almost exclusively by virtue of their access to the powers of office. They have greater name recognition (Cain, Ferejohn, and Fiorina, 1987), franking privileges (Mayhew, 1974), media coverage (Arnold, 2004; Prior, 2006; Ansolabehere, Snowberg, and Snyder Jr., 2006), and the ability to amass more contributions (Goodliffe, 2005).

The third set of theories applies a political strategy approach. Jacobson and Kernell (1983) argue that the primary reason for the success of incumbents is the weakness of challengers. Because people tend to vote based on recognition, and incumbents have easier access to voters, challengers avoid seeking an uphill electoral confrontation. Potential challengers only enter a race when they see a weak incumbent (Jacobson, 1990). This reasoning is consistent with models that explain voter preferences with long and mediumterm determinants. In a working class district, almost by definition, the candidate of the working class party will have an advantage over other parties' candidates. By backward induction, it is more likely that the working class party candidate will be the incumbent. Given that strong incumbents are not challenged and not all weak incumbents loose, incumbency re-election rates are inevitably higher. Jones (1999) finds that the presence of incumbent candidates on the ballot reduces the total number of candidates and parties contesting the election. The more incumbents seek re-election, the lower the effective number of candidates.

This third set of theories incorporates the role of resources, be it financial or other campaign assets. Challengers with more resources are more likely to topple incumbents (Banducci and Karp, 1994). As incumbents can use their name as a trademark, the amount of resources available for a challenger campaign is critical. However, the challenger must have a sufficiently high probability of winning to attract resources in the first place. Early in the campaign, challengers have little money because they are unknown and thus cannot build a successful campaign. Therefore, why would anyone financially support a challenger if the challenger is going to lose anyway? This self-fulfilling prophecy makes it difficult for incumbents to lose.

These theories that underline incumbency advantage have been developed in firstpast-the-post systems (FPTP). They assume that competition in single-member districts is generally between two parties. Under proportional representation (PR), party and campaign dynamics are different. In large districts with more seats to allocate, partisan incumbency advantage will weigh differently. In PR systems with closed lists, voters can only vote for parties. Thus, parties can affect re-elections rates and seniority levels simply by putting non-incumbents on the ballot. In PR systems with open-lists -where voters can select individual candidates- incumbents can also build their personal 
constituencies, but since several incumbents can be re-elected at once, the competition dynamics is different than in single-member districts.

In some special cases, and some unique dimensions, PR systems can be treated similar to FPTP systems. When the district magnitude is small, there are centripetal effects in the competition, making them resemble single-member districts. In Chile, with a fixed district magnitude of 2 in all districts, the PR system has centrifugal effects, but the competition occurs within each list (Magar, Rosenblum, and Samuels, 1998). Moreover, within each list, candidates seek the support of the median voter in their ideological niche.

The electoral system is often referred to as the "binominal system". It is a PR system, but because of the small district magnitude, it has been labeled semi-majoritarian (Nohlen and Fernández, 1999; Fernández, 1998). As each of the 60 districts in the Chamber of Deputies and each of the 19 senatorial districts elects 2 seats using PR, the system induces parties to group under two large coalitions. Those two coalitions, the center-left Concertación and the center-right Alianza, have won more than 95\% of the seats in the Chamber of Deputies since 1989. Parties form pre-electoral coalitions and present lists comprised of candidates from more than one party to compete for the two seats in every district. Voters select from an open-list of candidates. Like in single member districts, Chilean voters select individual candidates, but they do so within lists. The prevalence of the two coalitions has led some to treat Chile as a two-party system (Carey, 2002; Alemán and Navia, 2009; Aleman and Saiegh, 2007).

To allocate seats, votes are considered both for the sum of the list and for the individual candidates, using the d'Hondt formula. The first seat is awarded to the coalition with the largest share of votes. To win both seats, the list with most votes must receive twice as many votes as the second-place list. This means that in a two-list contest a party can obtain one seat with only one-third plus one votes. However, it must receive more than two thirds of the vote to obtain both seats. In a two-party contest, votes that the largest party gets beyond the one third threshold are useless, unless the party reaches the twothirds threshold (Magar, Rosenblum, and Samuels, 1998).

In practice, in each district the competition occurs between the two candidates within each coalition. Since the probability that a coalition will get both seats is small, candidates compete against their coalition partners for the one seat each coalition will likely get. That makes the competition within each coalition under the binominal system similar to the FTPT system in the U.S. Within every coalition in every district in Chile, there is the equivalent of the democratic/republican competition in each district in the U.S In both Chile and the U.S., the candidate with the most votes within each list wins. Despite having a PR system, Chile lends itself to comparisons with the U.S. because the effect of the electoral rules are similar in the two countries -between parties in the U.S. and within coalitions in Chile. This article contributes by applying theories of incumbency advantage developed for single-member districts to PR systems with the lowest possible magnitude.

This comparison can help expand the reach of existing theories beyond single member districts and explain patterns of incumbency advantage and re-election 
rates in proportional representation systems. A recurring feature in the region is the absence of term limits. With no term limits, the rate of re-election in the U.S. House of Representatives is greater than 90\% (Abramowitz, Alexander, and Gunning, 2006). Over 90 percent of Congressional incumbents that seek re-election are successful (Abramowitz, Alexander, and Gunning, 2006, 2008; Arnold, 1990; Mayhew, 1974; Jacobson, 1997). Part of the reason why the number is so high is that some incumbents retire when they fear losing. Logically, re-election rates are much lower in those countries with term limits (IDB, 2006). Those patterns have been historically stable (Camargo, 1965).

Few studies have attempted to explain incumbency advantage and tenure length at the legislative level in Latin America (Morgenstern and Nacif, 2002). Some have argued that Latin America has unique cultural patterns, and incumbency is based on sociological cleavages rather than on institutional determinants (Nolte, 1994). In addition, legislative elections in the U.S. are said to have different objectives than in Latin America, hindering comparative analysis (Samuels, 2002). Though the fact that the U.S. and Latin American countries have different electoral systems makes it difficult to apply the theories and methodologies developed for the U.S. case to Latin America, the similar incentives in the Chilean and U.S. electoral system lends itself to useful comparisons.

In fact, the burgeoning body of research on incumbency and tenure in Chile is mostly based on the methodology used and the evidence collected by scholars in the United States. Re-election rates are also high in Chile (Bunker, 2010; Morales and Piñeiro, 2010; Bunker and Navia, 2010). An elected position in Congress is the most desired by politicians, after the presidency (Carey, 1998).

The Chilean electoral rules have been cited as an incentive to seek re-election (Siavelis, 1997). In fact, most members of Congress aspire to either remain in the lower chamber, or advance to the Senate (Bunker, 2010). Moreover, tenure is encouraged by coalition elites, since party leaders are reluctant to deny incumbents the possibility of seeking re-election.

The high success rate of Chilean legislators who seek re-election is consistent with incumbency and tenure theories developed for single-member districts like in the U.S. The incumbent seems to hold an overwhelming advantage. Chilean incumbents have a natural advantage because the monetary cost of campaigning is relatively high. A candidate must invest around US $\$ 100,000$ to be competitive in a district of approximately 100,000 voters (Fuentes, 2004). Because of the high costs, and because incumbents are usually well known in their districts, parties strategically position strong challengers only where they stand a chance of winning. Alternatively, parties may nominate weak challengers to fill the space, or maverick challengers may withdraw to avoid losing the investment. In fact, incumbents are the candidates that spend most money and thus challengers must compete both against the recognition of the incumbent and her high investment (Morales and Piñeiro, 2010). Because of this entry barrier, coalitions often encourage incumbents to seek re-election. 


\section{HYPOTHESES}

Since the electoral rules in place lend the Chilean system comparable to that of the U.S., we present four hypotheses to assess incumbency advantage and tenure length in the Chilean Chamber of Deputies.

H1: Past electoral performance explains incumbents' decision to seek re-election. The larger the advantage over their intra-list challengers (list-partners) in the previous election, the more likely the incumbent is to seek re-election.

H2: Tenure length explains the incumbent's decision to seek re-election. The longer the tenure length, the more likely the incumbent is to seek re-election.

H3: Past electoral performance increases an incumbent's probability of winning a seat. The larger the advantage over their intra-list challengers (list-partners) in the previous election, the more likely the incumbent is to win a seat.

H4: Tenure length increases the incumbent's probability of winning a seat. The longer the tenure length, the more likely the incumbent is to win a seat.

\section{INCUMBENCY AND TENURE IN THE CHILEAN CHAMBER OF DEPUTIES}

In Chile's presidential democracy with a bicameral legislature, the president is both head of state and head of government, elected by absolute majority for a four-year term. The legislature consists of a Senate and a Chamber of Deputies. The electoral rules, established in the Constitution of 1980 -designed under authoritarian rule (1973-1990), were implemented for the first time in 1989 . Those rules have only been changed for local elections (in 1996, 2000 and 2004) and the upper chamber elections (in 2005), but not for the lower chamber. Between 1989 and 2009, there were five presidential, six legislative and five municipal elections. As in the U.S., Chilean legislators are not term-limited.

Electoral competition has evolved around two multi-party coalitions, the center-right Alianza and the center-left Concertación. The Alianza is comprised of the Independent Democratic Union (UDI) and National Renewal (RN). The Concertación is composed of the Christian Democratic Party (PDC), the Party for Democracy (PPD), the Socialist Party (PS) and the Social Democratic Radical Party (PRSD). In 2009, the Concertación also included the Communist Party (PC). Other parties are short-lived or small -and thus do not receive enough votes to either be elected or influence the election. Given the high threshold to obtain both seats, coalitions tend to send out one strong candidate, rather than take their chances with a relatively unknown or weak candidate (Edwards, 2009; Carey and Siavelis, 2003; Garrido and Navia, 2005).

Table 1 shows the high electoral disproportionality that the binomial system causes in favor of the two dominant coalitions. In 1989, the Concertación won 51.4\% of the votes and secured $57.5 \%$ of seats. The Alianza won $34.6 \%$ and $40 \%$ respectively. Consistently since then, the two coalitions have received a larger share of seats than votes, while 
others have mostly been unable to convert their small vote share into legislative seats. Independents are rarely elected to the legislature (Bunker, 2010).

Table 1. Votes and Seats in the Chamber of Deputies, 1989-2009

\begin{tabular}{ccccccc}
\hline & \multicolumn{2}{c}{ Alianza } & \multicolumn{2}{c}{ Concertación } & \multicolumn{2}{c}{ Others } \\
\hline & \% Votes & \% Seats & \% Votes & \% Seats & \% Votes & \% Seats \\
\hline 1989 & 34.1 & 40.0 & 51.4 & 57.5 & 12.5 & 2.5 \\
1993 & 36.6 & 41.6 & 55.4 & 58.3 & 7.2 & 0 \\
1997 & 36.2 & 39.1 & 50.5 & 57.5 & 13.5 & 3.3 \\
2001 & 44.2 & 47.5 & 47.9 & 51.6 & 7.8 & 0.8 \\
2005 & 38.7 & 45.0 & 51.7 & 54.1 & 9.5 & 0.8 \\
2009 & 43.4 & 48.3 & 44.3 & 47.5 & 12.1 & 4.1 \\
\hline
\end{tabular}

Source: Authors' with data from http://www.elecciones.gov.cl.

Table 2 shows information on Deputies who sought re-election and those who retired at the end of their terms. The percentage of incumbents who have retired has remained stable at around $25 \%$. As democracy has consolidated, the rate of legislators retiring has remained stable. Three out of 4 incumbents seek re-election. The rate of success among them has been stable. About 4 of every 5 deputies who seek re-election succeed.

In every congressional term, almost $60 \%$ of the legislators are incumbents. Thus, even though incumbents who seek re-election have a high level of success ( $82 \%$ average), each cohort has had a large number of first-termers. This is consistent with evidence found in re-election rates for mayoral elections, in which almost $60 \%$ of the mayors are on average re-elected incumbents (Bunker and Navia, 2010; Navia and Bunker, 2007).

Table 2. Incumbency and Re-Election Rates in the Chamber of Deputies, 1989-2013

\begin{tabular}{ccccccccr}
\hline Year & $\begin{array}{c}\text { Incumbents } \\
\text { who did not } \\
\text { seek re-election }\end{array}$ & \multicolumn{2}{c}{$\begin{array}{c}\text { Incumbents } \\
\text { seeking } \\
\text { re-election }\end{array}$} & \multicolumn{2}{c}{$\begin{array}{c}\text { Incumbents } \\
\text { re-elected }\end{array}$} & \multicolumn{2}{c}{ Freshmen class } \\
\hline & $\#$ & $\%$ & $\#$ & $\%$ & $\#$ & $\%$ & $\#$ & $\%$ \\
\hline 1993 & 33 & 28.0 & 87 & 72.5 & 70 & 80.4 & 50 & 41.7 \\
1997 & 34 & 28.3 & 86 & 71.6 & 73 & 84.8 & 47 & 39.2 \\
2001 & 28 & 23.0 & 92 & 76.6 & 75 & 81.5 & 45 & 37.5 \\
2005 & 28 & 23.0 & 92 & 76.6 & 77 & 83.6 & 43 & 35.8 \\
2009 & 29 & 24.0 & 91 & 75.8 & 74 & 81.3 & 46 & 38.3 \\
Average & 30.4 & 25.3 & 89.6 & 74.7 & 73.8 & 82.3 & 46.2 & 38.5 \\
\hline
\end{tabular}

Source: Authors' with data from http://www.elecciones.gov.cl. 
Figure 1 shows the makeup of the Chamber of Deputies elected in 2009 by their number of previous terms in office. Out of the 120 deputies elected in 2009, 62\% were returning, and $38 \%$ were elected to their first term. There is stability when compared to previous periods. Since 1989, on average, two in every five members of the Chamber have been freshmen.

Among those serving beyond their first term in 2009-2013, second termers comprise the largest group, twenty-nine deputies (24\%). Thus, 75 (63\%) legislators have been there for less than 8 years. Since 1989, six congressional terms have elapsed. Only 8 deputies (7\%) originally elected in 1989 are still in office. The fact that only 7 deputies have remained for 5 terms -those elected in 1993- shows that the length of stay is not directly linked with the fact that Congress has been functioning for only 20 years. In fact, only 25 deputies (21\%) have been in office for four or more periods. If the length of stay was associated with the transition to democracy, we should see a more linear relationship between tenure and the moment democracy was restored. But there seems to be a sharp drop in tenure length after the third term.

Figure 1. Tenure Length in Chamber of Deputies, 2009-2013

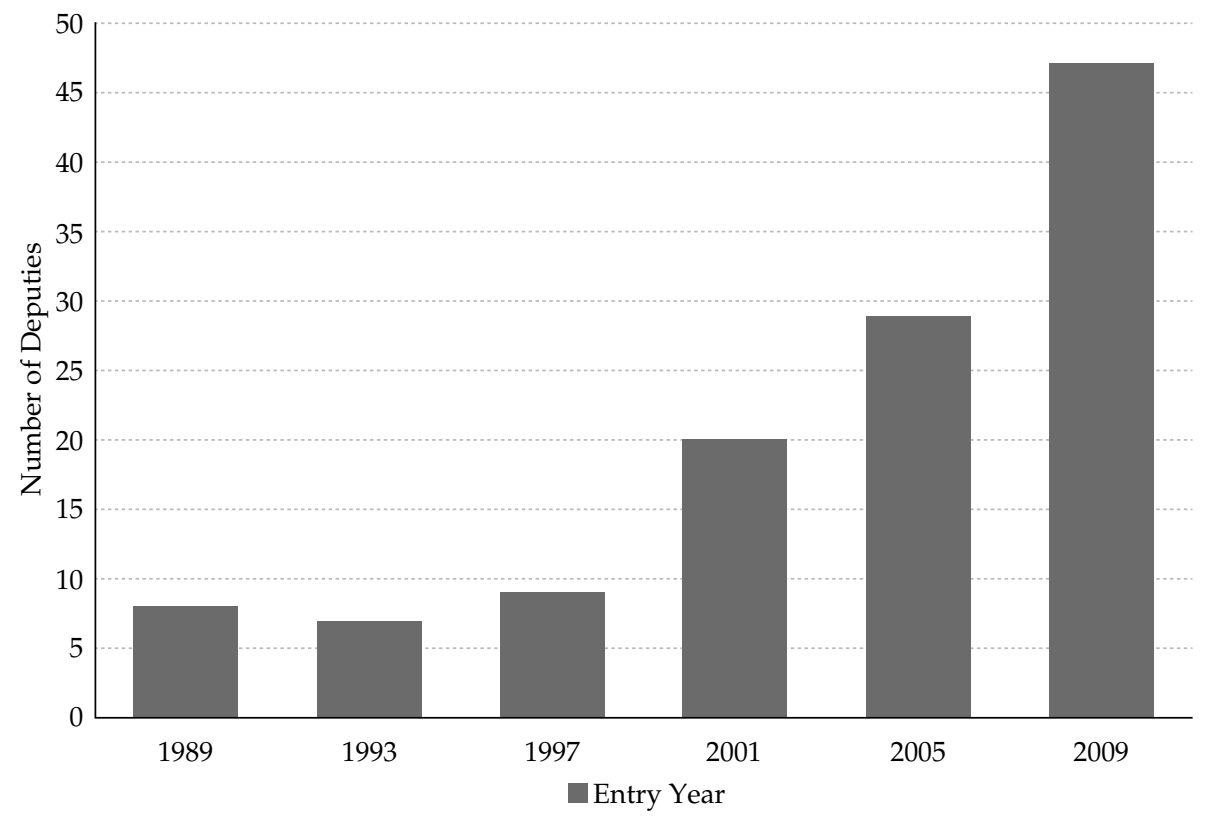

Source: Authors' with data from http://www.elecciones.gov.cl.

Table 3 shows the length of stay for every entering class since 1989. The first entering class was comprised of 120 deputies. Every entering class since has been smaller, with a high of 50 new deputies in 1993 and a low of 43 in 2005. The columns in Table 3 show the exit year. Inevitably, deputies entering in recent years have fewer possible 
exit years. Deputies starting in 2009 will have their first 'possible' exit in 2013. For every cohort of deputies, a higher number leave after their first term. However, as a percentage of the remaining class, the likelihood of survival does not increase with longer tenure.

For the first cohort, entering in 1989, the highest exit rate occurred at the end of their third and fourth periods. For the cohort entering in 1993, the highest exist rate occurred in their first, second and fourth periods. For more recent cohorts, it remains to be seen if their highest exit year will occur in later periods. However, a pattern emerges. About a third of every entering cohort of deputies loses at the end of their first period. The likelihood of survival does not seem to increase as legislators spend more time in Congress. Granted, the absolute number of legislators who have been for 4 or more terms in the Chamber of Deputies is getting larger (51 deputies), but more than half of them have retired or lost after their fourth term.

Table 3. Length of Stay for Entering Deputies, 1989-2013

\begin{tabular}{|c|c|c|c|c|c|c|c|}
\hline \multirow{2}{*}{ Entry year } & \multicolumn{6}{|c|}{ Exit year } & \multirow{2}{*}{ Total entering class } \\
\hline & 1993 & 1997 & 2001 & 2005 & 2009 & 2013 & \\
\hline 1989 & $\begin{array}{l}50 \\
(41.7 \%)\end{array}$ & $\begin{array}{l}28 \\
(23.3)\end{array}$ & $\begin{array}{l}20 \\
(16.7 \%)\end{array}$ & $\begin{array}{l}11 \\
(9.2 \%)\end{array}$ & $\begin{array}{l}3 \\
(2.5 \%)\end{array}$ & $\begin{array}{l}8 \\
(6.7 \%)\end{array}$ & $\begin{array}{l}120 \\
(100 \%)\end{array}$ \\
\hline 1993 & & $\begin{array}{l}19 \\
(38.0 \%)\end{array}$ & $\begin{array}{l}11 \\
(22.0 \%)\end{array}$ & $\begin{array}{c}6 \\
(12.0 \%)\end{array}$ & $\begin{array}{c}7 \\
(14.0 \%)\end{array}$ & $\begin{array}{c}7 \\
(14.0 \%)\end{array}$ & $\begin{array}{c}50 \\
(100 \%)\end{array}$ \\
\hline 1997 & & & $\begin{array}{l}14 \\
(29.8 \%)\end{array}$ & $\begin{array}{l}11 \\
(23.4 \%)\end{array}$ & $\begin{array}{l}12 \\
(25.5 \%)\end{array}$ & $\begin{array}{l}10 \\
(21.3 \%)\end{array}$ & $\begin{array}{c}47 \\
(100 \%)\end{array}$ \\
\hline 2001 & & & & $\begin{array}{l}15 \\
(33.3 \%)\end{array}$ & $\begin{array}{l}10 \\
(22.2 \%)\end{array}$ & $\begin{array}{l}20 \\
(44.4 \%)\end{array}$ & $\begin{array}{c}45 \\
(100 \%)\end{array}$ \\
\hline 2005 & & & & & $\begin{array}{l}14 \\
(32.6 \%)\end{array}$ & $\begin{array}{l}29 \\
(6.74 \%)\end{array}$ & $\begin{array}{c}43 \\
(100 \%)\end{array}$ \\
\hline 2009 & & & & & & $\begin{array}{c}46 \\
(100 \%)\end{array}$ & $\begin{array}{c}46 \\
(100 \%)\end{array}$ \\
\hline Total & 50 & 47 & 45 & 43 & 46 & 120 & $\begin{array}{l}351 \\
(100 \%)\end{array}$ \\
\hline
\end{tabular}

Source: Authors' with data from http:/ /www.elecciones.gov.cl

Table 4 shows the data organized differently. For every cohort, we classify deputies by the number of terms they have served. For the 1989 cohort, all members were firsttermers. In 2009, 46 were in their first term, 29 in their second term and 45 in their third or higher terms. Table 4 can be read diagonally to assess the relative weight of "experienced" deputies in every cohort. As democracy ages, older deputies will have served for more than 6 terms. But the number of deputies in their first, second and third terms has remained stable. 
Table 4. Tenure Length in Chamber of Deputies by Year of Election Cohorts, 1989-2013

\begin{tabular}{crrrrrrr}
\hline \multirow{2}{*}{ Congressional term } & \multicolumn{7}{c}{ Number of Terms Served at end of the period } \\
\cline { 2 - 8 } & 1 & 2 & 3 & 4 & 5 & 6 & Total \\
\hline $1989-93$ & 120 & - & - & - & - & - & 120 \\
$1993-97$ & 50 & 70 & - & - & - & - & 120 \\
$1997-01$ & 47 & 32 & 41 & - & - & - & 120 \\
$2001-05$ & 45 & 32 & 21 & 22 & - & - & 120 \\
$2005-09$ & 43 & 30 & 21 & 15 & 11 & - & 120 \\
$2009-13$ & 46 & 29 & 22 & 8 & 7 & 8 & 120 \\
Average $^{*}$ & 46.2 & 38.6 & 26.3 & 15.0 & 9.0 & 8.0 & 120 \\
\hline
\end{tabular}

Source: Authors' with data from http://www.elecciones.gov.cl.

* Excludes the first cohort.

Table 5 allows us to look at the time horizon of legislators. For every cohort, we show the number of terms that each deputy has served before and after that legislative period. For example, for the 120 deputies in the 1997-2001 period, 14 served for only one term, while 22 served for two terms (some of them were already on their second term in 1997). Though it mixes terms served before with terms served after, Table 5 shows the overall length of stay for all deputies in every term. A high number in the entering cohort of 1989 served only one term. For the 1993 cohort, the largest group was comprised of those who only served for two terms, probably reflecting the same phenomenon of politicians who ran for the Chamber when democracy was restored but who did not build careers, presumably due to their advanced age. In 1997 and 2001, the mode in terms served by deputies was three. Thus, even though there is a high re-election rate among deputies, there is also a relatively high replacement rate.

Table 5. Total Number of Legislative Periods by Chamber of Deputies Cohorts, 1989-2013

\begin{tabular}{lrrrrrr}
\hline & 1989 & 1993 & 1997 & 2001 & 2005 & 2009 \\
\hline One term & 50 & 19 & 14 & 15 & 14 & 46 \\
Two terms & 28 & 39 & 22 & 21 & 39 & 29 \\
Three terms & 20 & 26 & 38 & 38 & 32 & 12 \\
Four terms & 16 & 18 & 28 & 28 & 17 & 8 \\
Five terms & 3 & 10 & 10 & 10 & 10 & 7 \\
Six terms & 8 & 8 & 8 & 8 & 8 & 8 \\
Total & 120 & 120 & 120 & 120 & 120 & 120 \\
\hline
\end{tabular}

Source: Authors' with data from http:/ /www.elecciones.gov.cl. 
Table 6 shows the breakdown in number of terms for the 2009 cohort by coalition. The Alianza has more first-termers than in the Concertación. There are more second termers in the Concertación. This is probably due to the fact that the Alianza presidential candidate won in 2009 carrying Alianza legislators in his coattails while the winning Concertación candidate did the same in 2005. For those in their third terms and beyond, the number in the Concertación and Alianza are similar. Among legislators from parties outside the Alianza and the Concertación, there are three in the first term and one in his third term. Few independents and candidates from other parties are elected to the Chamber of Deputies. Many of them end up entering one of the Alianza or Concertación parties in their first term.

Table 6. Tenure in the Chamber of Deputies by coalition, 2009-2013

\begin{tabular}{lrrrrrrrr}
\hline & \multicolumn{2}{c}{ Alianza } & \multicolumn{2}{c}{ Concertación } & \multicolumn{2}{c}{ Others } & \multicolumn{2}{c}{ Total } \\
\hline & $\#$ & $\%$ & $\#$ & $\%$ & $\#$ & $\%$ & $\#$ & $\%$ \\
\hline First Term & 24 & 41.3 & 19 & 32.8 & 3 & 75.0 & 46 & 38.3 \\
Second Term & 12 & 20.6 & 17 & 29.3 & 0 & 0 & 29 & 24.2 \\
Third Term & 10 & 17.2 & 9 & 15.6 & 1 & 25.0 & 20 & 16.7 \\
Fourth Term & 4 & 6.8 & 6 & 10.3 & 0 & 0 & 10 & 8.3 \\
Fifth Term & 4 & 6.8 & 3 & 5.1 & 0 & 0 & 7 & 5.8 \\
Sixth Term & 4 & 6.8 & 4 & 6.8 & 0 & 0 & 8 & 6.6 \\
Total & 58 & 100 & 58 & 100 & 4 & 0 & 120 & 100 \\
\hline
\end{tabular}

Source: Authors' with data from http://www.elecciones.gov.cl.

* Includes the Communist Party.

Table 7 shows the tenure length of Deputies by coalition. Among the 143 individuals who have served in the Chamber since 1989 representing the Alianza, 42\% have served for only one term. The percentage is similar for the Concertación. Of the 200 legislators that have represented the Concertación since 1989, 44.5\% have served for only one term. Likewise, a large majority of independents has only served for one term. Table 7 shows that there are no differences in tenure length between Alianza and Concertación deputies. Belonging to a certain coalition does not seem to have an effect on the length of tenure in the Chamber of Deputies. Incumbents are not elected and re-elected based on the coalition they belong to.

Table 8 presents data on tenure length for the 2009-2013 cohort by party affiliation. Though there is no evidence of tenure patterns between coalitions, one may emerge within coalitions. Out of the 18 deputies from RN, 8 are first-termers. Only 5 PPD deputies -out of 18- and 3 PS -out of 11- are in their first terms. The average length of stay for current legislators is similar -around 2.4 terms- for all parties. Though rightwing parties normally criticize career politicians, the average length of tenure 
for deputies is similar for rightwing and leftwing legislators. However, there has been a larger turnover among rightwing parties than among leftwing parties in their legislative delegations.

Table 7. Tenure in the Chamber of Deputies by Districts, 1989-2013

\begin{tabular}{lrrrrrrrr}
\hline & \multicolumn{2}{c}{ Alianza } & \multicolumn{2}{c}{ Concertación } & \multicolumn{2}{c}{ Others } & \multicolumn{2}{c}{ Total } \\
\hline & $\#$ & $\%$ & $\#$ & $\%$ & $\#$ & $\%$ & $\#$ & $\%$ \\
\hline First Term & 60 & 42.0 & 89 & 44.5 & 6 & 85.7 & 155 & 44.2 \\
Second Term & 34 & 23.8 & 56 & 23.0 & 0 & 0 & 90 & 25.6 \\
Third Term & 25 & 17.5 & 33 & 16.5 & 1 & 14.3 & 59 & 16.8 \\
Fourth Term & 13 & 9.1 & 15 & 7.5 & 0 & 0 & 28 & 8.0 \\
Fifth Term & 7 & 4.9 & 3 & 1.5 & 0 & 0 & 10 & 2.8 \\
Sixth Term & 4 & 2.7 & 4 & 2.0 & 0 & 0 & 9 & 2.6 \\
Total & 143 & 100 & 200 & 100 & 7 & 100 & 350 & 100 \\
\end{tabular}

Source: Authors' with data from http://www.elecciones.gov.cl.

Note: Deputies who sit out for a term or more and then return to the same districts are counted twice.

Table 8. Tenure Length in the Chamber of Deputies, 2009-2013

\begin{tabular}{lcccccccccc}
\hline & \multicolumn{3}{c}{ Alianza } & \multicolumn{3}{c}{ Concertación } & \multicolumn{7}{c}{ Others } \\
\hline & RN & UDI & PPD & PS & PRSD & PDC & PRI & PCCH & IND & TOTAL \\
\hline First Term & 8 & 13 & 5 & 3 & - & 7 & 1 & 3 & 2 & $46^{*}$ \\
Second Term & 4 & 7 & 4 & 5 & 1 & 7 & - & - & - & $29^{* *}$ \\
Third Term & 1 & 9 & 4 & 1 & 2 & 1 & 2 & - & - & 20 \\
Fourth Term & 2 & 2 & 3 & - & 2 & 1 & - & - & - & 10 \\
Fifth Term & 2 & 2 & 2 & - & - & 1 & - & - & - & 7 \\
Sixth Term & 1 & 3 & - & 2 & - & 2 & - & - & - & 8 \\
Total & 18 & 36 & 18 & 11 & 5 & 19 & 3 & 3 & 2 & 120 \\
Average & 3 & 2.5 & 2.6 & 2.6 & 3.2 & 2.37 & 1.7 & 1 & 1 & 2.39 \\
\hline
\end{tabular}

Source: Authors' with data from http://www.elecciones.gov.cl.

* The total includes 3 independents elected for the Alianza and 1 for the Concertación.

** The total includes 1 independent re-elected for the Concertación.

Though we also collected data on the gender of the 720 deputies, women comprised only $10.5 \%$ of all the seats in the Chamber during the period, and less than $7 \%$ in the first two legislative terms. Similarly, legislators of indigenous descent have comprised less than $1 \%$ of all the seats in the Chamber. 


\section{EXPLAINING INCUMBENCY ADVANTAGE AND TENURE LENGTH IN CHILE}

As we discussed above, intra-coalition competition tends to be more important than inter-coalition competition. Thus, our unit of analysis is the race within each coalition in every district. Since there are 60 districts, for every election there can be up to 120 different races, 60 within the Concertación and 60 within the Alianza. We treat the races as single-member districts. In every district-level race, two Concertación candidates run against each other. In the large majority of races, only one of them will win a seat. The same happens in the Alianza. In the 6 elections held since 1989 in 60 districts, there were 720 different district level races in the two large coalitions.

Table 9 presents the breakdown of the match-up in those 720 races. In 607 (84.3\%), there were two candidates from each coalition and only one of them won a seat. The dynamics in the other races respond to different incentives. For example, in races where both candidates within the coalition win (a doblaje), one candidate normally gets elected due to the strong vote for the other candidate (an arrastrado, or a free rider). Given that the likelihood of doblajes is minimal, that free rider's decision to seek re-election is constrained by the decision of the winning candidate within her coalition. If that winning candidate chooses to run, the free rider can be considered an intra-list challenger again. In the case of doblado districts, there will be no incumbent within the district in the next election. Thus, those are open races. A few cases are what we categorize as loners, where there is only one candidate in a coalition and, thus, regardless of whether they win or lose, there is no intra-coalition competition.

Table 9. Breakdown of district level Chamber of Deputies races in Chile, 1989-2009

\begin{tabular}{lrrrrr}
\hline \multicolumn{1}{c}{ Type of match-up } & \# & $\%$ & $\begin{array}{c}\text { Vote difference } \\
\text { between first and } \\
\text { second place }\end{array}$ & $\begin{array}{c}\text { Standard } \\
\text { Deviation }\end{array}$ \\
\hline Normal (2 within-coalition candidates, one wins) & 607 & 84.3 & .16 & 0.111 \\
Doblados (2 within-coalition candidates, both lose) & 60 & 8.3 & $.10^{*}$ & 0.071 \\
Doblajes (2 within-coalition candidates, both win) & 47 & 7.7 & $.19^{*}$ & 0.150 \\
Loners (only 1 within-coalition candidate, wins or loses) & 6 & 0.8 & $.35^{*}$ & 0.129 \\
Total & 720 & 100 & .16 & .114 \\
\hline
\end{tabular}

Source: Authors' with data from www.elecciones.gov.cl.

* Statistically significant at the $99 \%$ level (0.01), when compared to a normal race.

** Loners have no running mate, thus the vote differential is their average vote.

Figure 2 shows the vote difference between the winner and loser in the four different types of matchups. Normal matchups, when the coalition had two candidates and only 
got won a seat, have a very small variance. The winning candidate gets an average vote share $16 \%$ higher than the losing candidate. This type of races is not very competitive. True, when both candidates lose (and the coalition fails to win a seat in the district), the race is more competitive, but this is because neither candidate had a sufficiently high vote -both candidates receive a vote share that is normally single digits. When the coalition secures both seats -doblajes- the vote difference is higher, thus pointing to the fact that one candidate is 'arrastrado' (pulled-in) by the more popular candidate. The case of loners simply reflects the vote share that the sole candidate of the coalition received. In five cases, loners won a seat and in one case, the loner lost the seat.

Figure 2. Intra-coalition vote differential in Deputies races by matchup type, 1989-2009

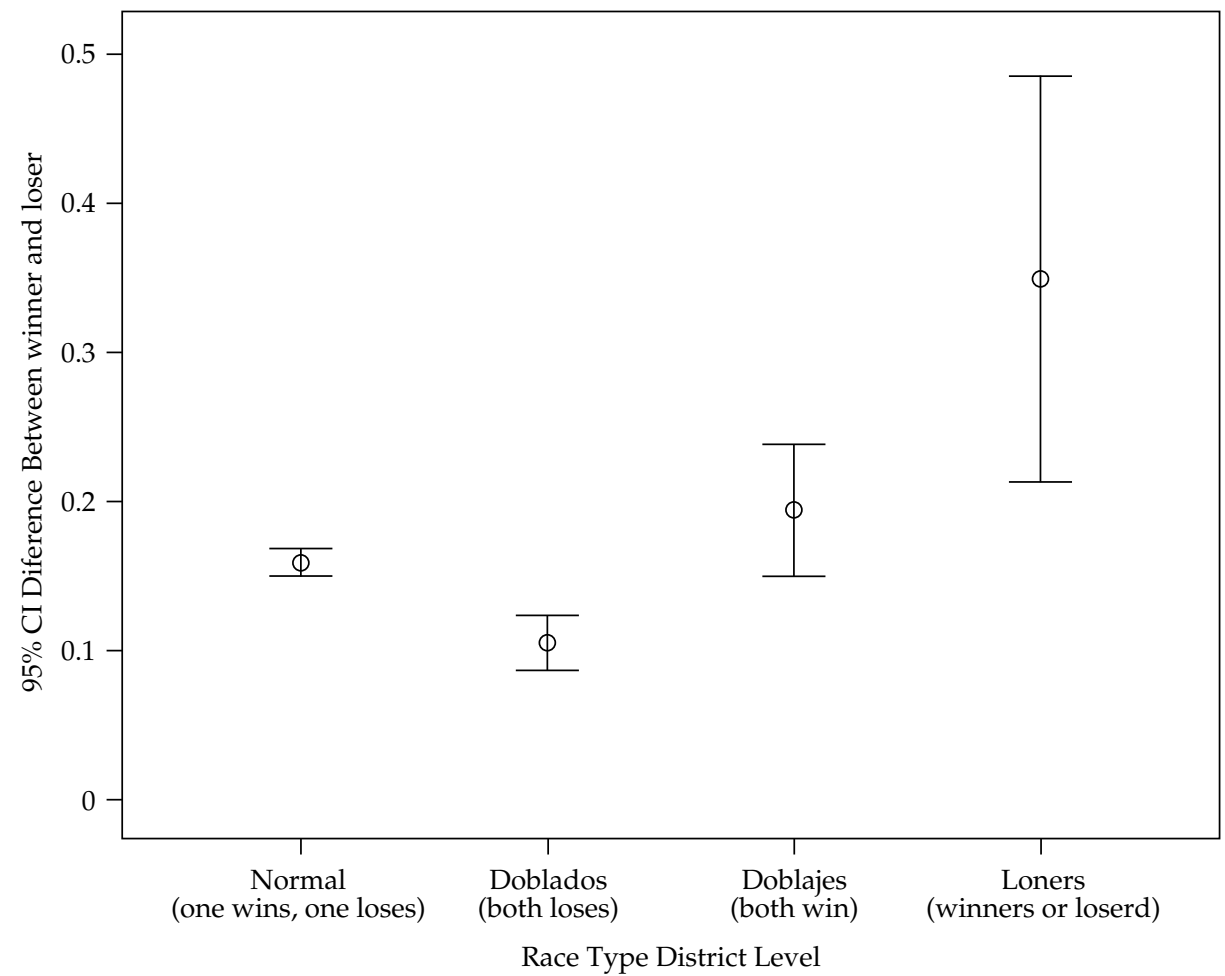

We now turn to our first hypothesis. Our expectation is that the larger the margin of victory in the previous election, the more likely an incumbent is to seek re-election. A larger margin of victory should make incumbents feel safer and can potentially dissuade future challengers.

Table 10 shows the intra-coalition vote difference by election year for all the normal races separating those who sought re-election 4 years later from those who did not. The number of district-level races is 493 . There is stability in the vote difference over time. Intra-coalition winners with a higher vote differential should be more likely to seek re- 
election four years later. However, Table 10 shows the opposite. Intra-coalition winners who do not seek re-election four years later have a higher margin of victory than those who do seek re-election later.

This unexpected result can be explained by the fact that many such intra-coalition winners run for the Senate instead of seeking re-election to the Chamber. If we exclude intra-coalition winners who run the Senate, the average vote differential for those who do not seek re-election declines sharply from 0.17 to 0.13 .

With the descriptive evidence in Table 10, we find mixed evidence for our first hypothesis. Overall, past electoral performance does not explain incumbents' decision to seek reelection. However, when we exclude incumbents who run for the Senate, a higher margin of victory in the previous election makes it more likely for incumbents to seek re-election.

Table 10. Intra-coalition vote differential in normal matchups by decision to run for reelection four years later, 1989-2009

\begin{tabular}{lccccccccr}
\hline & \multicolumn{2}{c}{$\begin{array}{c}\text { Seek re-election } \\
\text { (4 years later) }\end{array}$} & \multicolumn{4}{c}{$\begin{array}{c}\text { Do not seek re-election } \\
\text { (4 years later) }\end{array}$} & \multicolumn{3}{c}{ Total 4 years later } \\
\hline & $\begin{array}{c}\text { Vote } \\
\text { Difference }\end{array}$ & Std. dev & $\#$ & $\begin{array}{c}\text { Vote } \\
\text { difference }\end{array}$ & Std. dev & $\#$ & $\begin{array}{c}\text { Vote } \\
\text { difference }\end{array}$ & Std. dev & $\#$ \\
\hline $1989-1993$ & .13 & .105 & 69 & .15 & .118 & 22 & .14 & .108 & 91 \\
$1993-1997$ & .16 & .111 & 71 & .16 & .106 & 25 & .16 & .109 & 96 \\
$1997-2001$ & .15 & .105 & 72 & .22 & .105 & 21 & .16 & .116 & 93 \\
$2001-2005$ & .19 & .119 & 85 & .14 & .114 & 23 & .18 & .119 & 108 \\
$2005-2009$ & .16 & .106 & 83 & .18 & .116 & 22 & .16 & .108 & 105 \\
Average & .158 & - & - & .170 & - & - & .160 & - & - \\
\hline
\end{tabular}

Source: Authors' with data from http://www.elecciones.gov.cl.

We also conduct a logistic regression to test our first and second hypotheses. Table 11 shows the odds ratios for the effect of the vote differential in the previous election and tenure length (measured in the number of previous terms in office) on the decision that an incumbent will seek re-election. Since only incumbents can seek re-election, we use the data on incumbents that served between 1989 and 2009. Since our dependent variable is the decision to seek re-election, we exclude the 1989 election. Thus, we analyze the incumbents' decision to seek re-election in all the elections between 1993 and 2009. We present three models, one for Alianza incumbents, one for Concertación incumbents and one for all incumbents from both coalitions.

The models present interesting results. Since we use odd ratios, the values above 1 indicate a higher probability of seeking re-election while the values below 1 indicate a lower probability of seeking re-election. The odds ratio for vote differential in the previous elections does not have a statistically significant effect on the decision to seek re- 
election in any of the models. This is consistent with the descriptive evidence presented in Table 10. For the Alianza, a longer tenure length makes it less likely for incumbents to seek re-election, while for the Concertación, tenure length has a statistically significant positive effect.

When we combine all incumbents from both coalitions, we find that neither the vote differential in the previous election nor tenure length have an effect on the decision to seek re-election. Thus, the logistic regression fails to prove our first and second hypotheses. Incumbent deputies with a larger vote difference in the previous election are not more likely to seek re-election in Chile. Similarly, only Concertación incumbents with a longer tenure are more likely to seek re-election. In part, this might be due to the fact that the Alianza has fewer legislators than the Concertación. Since the number of Concertación and Alianza deputies that run for Senate seats is comparable, the relative weight of those Alianza deputies that seek a Senate is higher in the rightwing coalition. Thus, tenure length matters more for Concertación deputies to seek re-election than for Alianza legislators.

Table 11. Logistic regression on incumbents' decision to seek re-election, 1993-2009

\begin{tabular}{lccc}
\hline & Alianza & Concertación & Alianza and Concertación \\
\hline $\begin{array}{lccc}\text { Vote differential in previous election } \\
(0-100)\end{array}$ & $\begin{array}{c}1.165 \\
(1.717)\end{array}$ & 0.285 & 0.474 \\
& $0.736^{* *}$ & $1.266^{*}$ & $(0.400)$ \\
Number of terms in power (1-5) & $(0.101)$ & $(0.173)$ & 0.989 \\
N & 252 & 292 & $(0.093)$ \\
LR chi2 & 4.90 & 4.16 & 544 \\
Prob > chi2 & 0.086 & 0.124 & 0.85 \\
Pseudo R2 & 0.019 & 0.011 & 0.654 \\
Log likelihood & -124.480 & -172.220 & 0.001 \\
\hline
\end{tabular}

Dependent variable: does the incumbent seek reelection?

Standard Errors in parenthesis.

**: significant at the 0.05 level (5\%), *: significant at the 0.1 level (10\%).

Our third and fourth hypotheses assess the effect of past electoral performance and tenure length on the probability that an incumbent is re-elected. Table 12 shows the odds ratios for the three models, on Alianza incumbents, Concertación incumbents and incumbents from both coalitions lumped together.

The results show a strong effect of the vote differential in the previous election on the probability that Alianza incumbents win re-election. For the Concertación -and for all incumbents together- the effect of the vote differential in the previous election is 
not statistically significant. Thus, we can only partially support our third hypothesis. The vote differential in the previous election only seems to increase the probability of winning a seat for Alianza incumbents. The result for Concertación incumbents is somewhat surprising. Anecdotal evidence would suggest that many Concertación legislators who do very well in the previous election opt to run for the Senate rather than seek re-election.

Our fourth hypothesis associates tenure length with an incumbent's higher probability of winning a seat. The models in Table 12 suggest that this is true only for Concertación incumbents. For Alianza incumbents, the number of previous terms in office actually has a statistically significant negative effect on the incumbent's probability of winning a seat. This might have something to do with the fact that, for the entire period we study, the Concertación was the ruling coalition. If incumbents build support by providing constituency services, it is more likely that ruling coalition incumbents will be more effective in delivering those services than incumbents from the opposition. Though there is not sufficient data to test the feasibility of that claim -since there was no variance on the ruling coalition for the period we studythe claim is consistent with what has been reported elsewhere on how incumbency advantage works. In addition, because for Alianza legislators seeking re-election the vote differential in the previous election has a significant effect -but not the number of terms in office- we can speculate that constituency service matters less for Alianza legislators than their previous name recognition. As Alianza legislators were always in the opposition, they could not build support based on their longterm service the same way as Concertación legislators did.

Table 12. Logistic regression on the probability that incumbents are re-elected, 1993-2009

\begin{tabular}{lccc}
\hline & Alianza & Concertación & $\begin{array}{c}\text { Alianza and } \\
\text { Concertación }\end{array}$ \\
\hline Vote differential in previous election (0-100) & $26.877^{* * *}$ & 0.782 & 2.783 \\
& $(35.437)$ & $(0.758)$ & $(2.143)$ \\
Number of terms in office (1-5) & $0.793^{*}$ & $1.506^{* * *}$ & 1.110 \\
N & $(0.099)$ & $(0.196)$ & $(0.095)$ \\
LR chi2 & 252 & 292 & 544 \\
Prob > chi2 & 8.18 & 11.09 & 3.99 \\
Pseudo R2 & 0.016 & 0.003 & 0.135 \\
Log likelihood & 0.025 & 0.027 & 0.005 \\
\hline
\end{tabular}

Dependent variable: is the incumbent reelected?

Standard Errors in parenthesis.

***: significant at the 0.01 level $(1 \%), *$ significant at the 0.1 level $(10 \%)$. 


\section{CONCLUSION}

After 24 years of democracy in Chile, the Chilean legislature presents high levels of incumbents who seek re-election $(74.6 \%)$ and high re-election rates $(82.3 \%)$. Because the average tenure length in the Chamber of Deputies is 2.4 terms, there is still a healthy turnover rate. Every 4 years, $38.5 \%$ of the 120 -member Chamber of Deputies is comprised of first-termers. Because the electoral system induces more intra-coalition and inter-coalition competition, we analyzed the effect of incumbency advantage within coalitions.

We found that past electoral performance does not explain an incumbent's decision to seek re-election. Those incumbents who had a larger advantage over their intra-list challengers (list-partners) in the previous election are not more likely to seek re-election in Chile. Similarly, a longer tenure length explains the incumbent's decision to seek reelection only for Concertación incumbents. In the Alianza, a longer tenure length actually makes it less likely that incumbents will seek re-election.

Past electoral performance has a strong effect on increasing the probability that Alianza incumbents retain their seat. But for Concertación incumbents, a larger advantage over their intra-list challengers (list-partners) in the previous election does not make it more likely for them to win a seat. Finally, tenure length increases the incumbent's probability of winning a seat only for incumbents from the Concertación. For the Alianza, a longer the tenure length makes it less likely that incumbents will win re-election.

As democracy consolidates in Chile and data on re-election rates and tenure length in the Chamber of Deputies accumulates, some interesting patterns emerge. As the government has changed hands between the Concertación and Alianza, future research will be able to assess how incumbency advantage and tenure length interact in Congress with having control of the executive. Given Chile's strong presidential system, we suspect that tenure length will matter more for legislators from the ruling coalition. Future research should also examine why past electoral performance -measured as the vote differential in the previous election- does not have an effect on an incumbent's decision to seek re-election and his/her probability of winning a seat.

\section{REFERENCES}

Abramowitz, Alan, Brad Alexander, and Matthew Gunning. 2006. “Don't Blame Redistricting for Uncompetitive Elections". PS: Political Science and Politics 39 (1): 87-90.

Abramowitz, Alan, Brad Alexander, and Matthew Gunning. 2008. "Incumbency, redistricting, and the decline of competition in US House elections". The Journal of Politics 68 (01): 75-88.

Aleman, Eduardo and Sebastian M. Saiegh. 2007. "Legislative preferences, political parties, and coalition unity in Chile". Comparative Politics 39 (3):253-272.

Alemán, Eduardo, and Patricio Navia. 2009. “Institutions and the Legislative Success of 'Strong' Presidents: An Analysis of Government Bills in Chile". Journal of Legislative Studies 15 (4): 401-419.

Alesina, Alberto, and Howard Rosenthal. 1995. Partisan Politics, Divided Government and the Economy. New York: Cambridge University Press. 
Angus, Campbell, Pihilip E Converse, Warren E Miller, and Donald E Stokes. 1960. The American Voter. New York: Wiley.

Ansolabehere, Stephen, Erik C. Snowberg, and James M. Snyder Jr. 2006. “Television and the incumbency advantage in US elections". Legislative Studies Quarterly 31 (4): 469-490.

Ansolabehere, S., J.M. Snyder Jr, and Charles Stewart III. 2000. “Old Voters, New Voters, and the Personal Vote: Using Redistricting to Measure the Incumbency Advantage". American Journal of Political Science: 17-34.

Ansolabehere, Stephen, and James M. Snyder. 2002. "The Incumbency Advantage in U.S. Elections: An Analysis of State and Federal Offices, 1942-2000". Election Law Journal 1 (3): 315-338.

Arnold, Douglas R. 1990. The Logic of Congressional Action. New Haven: Yale University Press.

Arnold, Douglas R. 2004. Congress, the Press, and Political Accountability. New Jersey: Princeton University Press.

Banducci, Susan, and Jeffrey A. Karp. 1994. "Electoral Consequences of Scandal and Reapportionment in the 1992 House Elections". American Politics Research 22 (3): 3-26.

Bunker, Kenneth, and Patricio Navia. 2010. "Democracia comunal en Chile, 1992-2008". Política y gobierno 17 (2): 243-278.

Bunker, Kenneth. 2010. "Cambio y Continuidad en la Cámara de Diputados, 1989-2014". In El Sismo Electoral de 2009, edited by Mauricio Morales and Patricio Navia, 185-201. Santiago: Universidad Diego Portales.

Cain, Bruce, John Ferejohn, and Morris Fiorina. 1987. The Personal Vote. Cambridge: Harvard University Press.

Camargo, Pedro Pablo. 1965. Reelección Presidencial y Reelección Parlamentaria en América y México. México D.F.: Universidad Nacional Autónoma de México.

Carey, John M. 1998. Term Limits and Legislative Representation. Cambridge: Cambridge University Press.

Carey, John M. 2002. "Parties, Coalitions, and the Chilean Congress in the 1990s "In Legislative Politics in Latin America, edited by Scott Morgerstern and Benito Nacif, 222-253. New York: Cambridge University Press.

Carey, John M., and Peter Siavelis. 2003. "El Seguro para los Subcampeones Electorales y la Sobrevivencia de la Concertación". Estudios Públicos 90: 5-27.

Cox, Gary W., and Jonathan N. Katz. 1996. "Why Did the Incumbency Advantage Grow?". American Journal of Political Science 40 (2): 478-497.

Dahl, Robert. 1971. Polyarchy. Participation and Opposition. New Haven: Yale University Press.

Desposato, Scott W., and John R. Petrocik. 2003. "The Variable Incumbency Advantage: New Voters, Redistricting, and the Personal Vote". American Journal of Political Science 47 (1): 18-32.

Edwards, Santiago. 2009. "Jugando a perdedor: Candidatos con improbables posibilidades de triunfo en elecciones parlamentarias en Chile en 2005". In Genoma Electoral Chileno: Dibujando el Mapa Genético de las Preferencias Políticas en Chile, edited by Patricio Navia, Mauricio Morales and Renato Briceño, 165-185. Santiago: Ediciones Universidad Diego Portales.

Erikson, Robert S. 1971. "The Advantage of Incumbency in Congressional Elections". Polity 3: 395-405.

Fenno, Richard. 1978. Home Style: House Members in their Districts. New York: Longman.

Ferejohn, John. 1995. “The Spatial Model and Elections.” In Information, Participation and Choice: An Economic Theory of Democracy in Perspective, edited by Bernard Grofman, 107-124. Ann Arbor: University of Michigan Press.

Ferejohn, John A. 1977. "On the decline of Competition in Congressional Elections". American Political Science Review 28: 127-146.

Fernández, Mario. 1998. "El sistema político chileno. Características y tendencias". In Chile en los noventa, edited by Cristián Toloza and Eugenio Lahera. Santiago: Presidencia de la República/DOLMEN.

Fiorina, Morris P. 1989. Congress. Keystone of the Washington Establishment. New Haven: Yale University Press.

Fowler, Anthony and Andrew Hall. 2012. The Incumbency Advantage is Personal: Evidence from Regression Discontinuity and Term Limits in State Legislatures. Working Paper.

Fuentes, Claudio. 2004. El Costo de la Democracia. Santiago: FLACSO.

Gaines, Brian J. 1998. "The Impersonal Vote? Constituency Service and Incumbency Advantage in British Elections, 1950-1992". Legislative Studies Quarterly 23 (2): 167-195.

Garrido, Carolina, and Patricio Navia. 2005. "Candidatos fuertes en la Concertación: ¿Seguro para subcampeones o prevalencia de los tres tercios?". Estudios Públicos 99 (Invierno): 165-194.

Goodliffe, Jay 2005. “When Do War Chests Deter?". Journal of Theoretical Politics 17 (2): 249-277.

Gordon, Sanford C. and Dimitri Landa. 2009. "Do the advantages of incumbency advantage incumbents?". The Journal of Politics 71 (4): 1481-1498. 
Jacobson, Gary C. and Samuel Kernell. 1983. Strategy and choice in congressional elections. New Haven: Yale University Press.

Jacobson, Gary C. 1981. "Incumbents advantage in the 1978 U.S. Congressional Elections". Legislative Studies Quarterly 6 (2): 183-200.

Jacobson, Gary C. 1990. The Electoral Origins of Divided Government: Competition in U.S. House elections, 1946-1988. San Francisco: Westview.

Jacobson, Gary C. 1997. The Politics of Congressional Elections. 4th edition. New York: Longman.

Jones, Mark P. 1999. "Electoral Laws and the Effective Number of Candidates in Presidential Elections". Journal of Politics 61 (1): 171-184.

Lazarsfeld, Paul, Bernard Berelson, and Hazel Gaudet. 1944. The People's Choice. New York: Columbia University Press.

Magar, Eric, Marc. R Rosenblum, and David Samuels. 1998. “On the Absence of Centripetal Incentives in Double-member Districts. The Case of Chile". Comparative Political Studies 31 (6): 714-739.

Mayhew, David R. 1974. "Congressional Elections: The Case of the Vanishing Marginals". Polity 6: 295-317.

Morales, Mauricio, and Rafael Piñeiro. 2010. "Gasto en campaña y éxito electoral de los candidatos a diputados en Chile 2005". Revista de Ciencia Política 30 (3): 645-667.

Morgenstern, Scott, and Benito Nacif, eds. 2002. Legislative Politics in Latin America. New York: Cambridge University Press.

Mustapic, Ana María. 2006. “Bajo Nivel de Reelección en el Congreso." La Nación, Argentina (August 18).

Navia, Patricio, and Kenneth Bunker. 2007. “Elecciones municipales y reelección de alcaldes en Chile: 19922004". En Foco Corporación Expansiva 125.

Nohlen, Dieter, and Mario Fernández, eds. 1999. Presidencialismo versus parlamentarismo. Santiago: Editorial Nueva Sociedad.

Nolte, Detlef. 1994. “Procesos electorales y Partidos Políticos: Tendencias y Perspectivas en la Década de los Noventa". Perfiles Latinoamericanos 3 (5): 7-36.

Parker, Glenn R. 1980. "The advantage of incumbency in House Elections". American Politics Quarterly 8: 449-464.

Popkin, Samuel L. 1995. "Information Shortcuts and the Reasoning Voter". In Information, Participation and Choice: An Economic Theory of Democracy in Perspective, edited by Bernard Grofman, 17-35. Ann Arbor: The University of Michigan Press.

Prior, Markus. 2006. "The Incumbent in the Living Room: The Rise of Television and the Incumbency Advantage in US House Elections". Journal of Politics 68 (3): 657-673.

Przeworski, Adam. 1991. Democracy and the Market. Cambridge: Cambridge University Press.

Samuels, David. 2002. "Pork-Barreling is Not Credit-Claiming or Advertising: Campaign Finance and the Sources of the Personal Vote in Brazil". The Journal of Politics 64 (3): 845-863.

Siavelis, Peter. 1997. "Continuity and Change in the Chilean Party System". Comparative Political Studies 30 (6): 651-674.

Tufte, Edward R. 1973. "The Relationship Between Seats and Votes in Two-Party Systems". American Political Science Review 67 (2): 540-554.

Kenneth Bunker is a PhD. Candidate in Political Science at The London School of Economics and Political Science. He holds a B.A. in Political Science from Universidad Diego Portales; a M.A. in Political Science from San Diego State University; a MRes. in Political Science from The London School of Economics and Political Science. He has published in Electoral Studies, Journal of Politics in Latin America, Política y Gobierno and Revista Española de Ciencia Política.

E-mail: k.a.bunker@lse.ac.uk.

Patricio Navia is a master teacher in Liberal Studies and adjunct professor in the Center for Latin American and Caribbean Studies at New York University. He is also a researcher and full professor of Political Science at the Facultad de Ciencias Sociales at Universidad Diego Portales in Chile. He holds a B.A. in Political Science and Sociology from the University of Illinois at Chicago; a M.A. in Political Science from University of Chicago, and a PhD. in Politics from New York University. He has published in Latin American Research Review, Journal of Legislative Studies, Comparative Political Studies and Journal of Democracy.

E-mail: patricio.navia@udp.cl. 
